\title{
Distance Learning and Character Building in Rural Area During the Covid-19 Pandemic
}

\section{Putu Mas Dewantara1*, I Ketut Dibia ${ }^{2}$}

${ }^{1}$ Jurusan Bahasa Sastra Indonesia dan Daerah, Universitas Pendidikan Ganesha, Singaraja, Indonesia

2 Jurusan Pendidikan Dasar, Universitas Pendidikan Ganesha, Singaraja, Indonesia

\section{ART I CLE IN F O}

\section{Article history:}

Received August 10, 2021

Revised August 11, 2021

Accepted October 20, 2021

Available online November 25, 2021

\section{Kata Kunci:}

Pembelajaran Jarak Jauh, Karakter, Rural Area

Keywords:

Distance Learning, Character, Rural Area

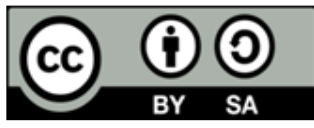

This is an open access article under the CC BY-SA license.

Copyright (ㅇ 2021 by Author. Published by Universitas Pendidikan Ganesha.

\begin{abstract}
A B S T RAK
Pandemi covid-19 telah membawa sejumlah kendala dan tantangan dalam pembelajaran. Kendala semakin besar ditemui bagi sekolahsekolah di rural area. Mulai dari masalah ketersediaan sarana penunjang, dukungan orang tua, sampai kepada masalah kesiapan guru dalam melaksanakan pembelajaran dan pendidikan karakter di masa pandemi covid-19. Oleh karena itu penelitian ini bertujuan mendeskripsikan strategi guru dalam melaksanakan pembelajaran jarak jauh dan pendidikan karakter di rural area pada masa pandemi Covid-19. Penelitian ini adalah penelitian kualitatif yang melibatkan 13 orang guru. Metode pengumpulan data berupa metode observasi, wawancara, dan kuesioner. Analisis data dilaksanakan secara deskriptif kualitatif. Pengolahan data melalui tiga tahap model alir, yaitu reduksi data, penyajian data, dan verifikasi data. Pemeriksaan keabsahan data dilakukan melalui teknik triangulasi sumber, metode, dan teori. Hasil penelitian ini menunjukkan strategi guru dalam melaksanakan pembelajaran jarak jauh meliputi: pembelajaran jarak jauh daring berbasis Whatsapp, pembelajaran jarak jauh luring, dan pembelajaran jarak jauh campuran. Ada 3 strategi yang dilakukan dalam pendidikan karakter di masa pandemi Covid-19, yaitu melalui nasihat langsung; melalui contoh-contoh atau narasi dalam teks. Contoh yang diberikan juga berupa gambar; dan melalui cek list aktivitas harian dan mingguan. Berbagai kendala terjadi dalam pembelajaran jarak jauh dan pendidikan karakter. Orang tua juga merasa stres karena bertambahnnya beban. Oleh karena itu, perlu kerjasama antara berbagai komponen untuk mendesain strategi pembelajaran yang paling efektif di rural area.
\end{abstract}

\begin{abstract}
A B S T R A C T
The COVID-19 pandemic has brought a number of obstacles and challenges in learning. The bigger obstacle is found for schools in rural areas. Starting from the problem of the availability of supporting facilities, parental support, to the problem of teacher readiness in carrying out learning and character education during the COVID-19 pandemic. Therefore this study aims to describe the teacher's strategy in carrying out distance learning and character education in rural area during the Covid-19 pandemic. This research was a qualitative research, involving 13 teachers. The data were collected through observation, interview, and questionnaire. The data analysis was carried out in by using a qualitative descriptive analysis. The data were analyzed through three stages, namely data reduction, data presentation, and data verification. The data were validated through source, method, and theory triangulations. The results of this study indicate that the teachers' strategies in implementing distance learning include: Whatsapp-based online distance learning, offline distance learning, and mixed distance learning. There were 3 strategies to carry out character education during the Covid-19 pandemic, namely direct feedback through examples or narrative in the text. Examples given were also in the form of pictures; and through a checklist of daily and weekly activities. Various obstacles occured in distance learning and character education. Parents also felt stressed because of the increased burden during the pandemic. Therefore, collaboration between various components is needed to design the most effective learning strategies in rural areas.
\end{abstract}




\section{INTRODUCTION}

In Distance Learning, teachers have an important role in helping students deal with uncertainty and engaging students to continue learning (Hanesty et al., 2020; Stojanović et al., 2021). Policies are enacted to regulate distance learning during the covid-19 pandemic, such as distance learning must be able to provide a meaningful learning experience for students without being burdened with the demands of completing all curriculum achievements of grade promotion and graduation (Lemay et al., 2021; Sari et al., 2020; Sindiani et al., 2020). Distance Learning is carried out by focusing on life skills education, including those regarding Covid-19; Distance Learning is implemented by providing a variety of learning activities and tasks; and Distance Learning is carried out by providing feedback on products of learning activities qualitatively that are useful for teachers without being required to give quantitative scores. Similar policies are also implemented in other countries due to the various challenges that exist (Bokayev et al., 2020; Cha \& So, 2021; Joaquin et al., 2020).

Schools with the support of the readiness of educators, students, facilities, and access to carry out online learning certainly do not encounter many obstacles in the implementation of Distance Learning. However, obstacles arise when one of the various supporting factors for the implementation of online learning is not met, as experienced in rural areas (Aditya, 2015; Arkiang, 2021). Various factors also influence each other in providing education during the pandemic for rural areas. Almost a year has passed, distance learning still encounters a number of problems, especially in rural areas. This situation is as shown from the results of observations at 2 elementary schools in the rural area of Jembarana District, namely SD Negeri 2 Perancak and SD Negeri 1 Yeh Kuning. These two schools are located on the outskirts of Jembrana District. Judging from internet access, both schools have access support. However, the economic situation of the students' parents is the main problem. This situation is similar to some other rural areas, but the economy of parents is a determining factor in the ability to use internet access. In addition, the readiness of teachers so far in conducting distance learning in the form of online learning is still relatively low (Andarwulan et al., 2021; Churiyah et al., 2020; Mansur et al., 2021).

Another situation that is often problematic during the Covid-19 pandemic is character education. Research involving respondents from parents of students shows that parents during online learning were not able to build their child's character optimally without the help of the teacher (Aji, 2020; Tiwery et al., 2021). Parents believed that teachers really help them in shaping and building the character of their children. They felt that the presence of teachers in building children's character was very much needed. This study shows the very important role of the teacher in character education of children. Schools (teachers) had a strategic role in the formation of children's character (Pradana et al., 2021; Simbolon et al., 2021). This opinion is increasingly relevant seeing the results which gives an important position for teachers to continue to provide character education for students while studying from home (Aji, 2020; Pradana et al., 2021). Changes in the learning environment affect the psychological condition of children. This condition has an impact on the character education of students (Akhwani \& Romdloni, 2021). The difficult situation in carrying out character education was also experienced in the two schools. One way that has been done by teachers in carrying out character education is through the insertion of feedback through WhatsApp groups. However, a preliminary study showed other obstacles faced in this way, such as constraints due to socio-economic factors that have an impact on the lack of time for mentoring by parents. This obstacle is increasingly felt in the lower classes.

Looking at the situation and strategies that exist in the two schools and previous researches related to distance learning (Atsani, 2020; Dewi, 2020; Prabowo et al., 2020) and related to character education (Mustikaningrum et al., 2020; Prabowo et al., 2020; Yoga Purandina \& Astra Winaya, 2020). It is necessary to conduct a case study to see how distance learning and character education are carried out in elementary schools in rural areas. The state of the art of this research lies in an in-depth search that looks at how online learning is implemented and character education is carried out in rural areas with all the existing limitations. Previous studies looked at online learning studies in terms of learning constraints, teacher readiness, literature review of online learning from articles and news, online learning media, and the use of technology (Atsani, 2020; Ayuni et al., 2021; Dewi, 2020). In-depth case studies in rural areas have never been conducted. Rural areas are areas that have more complex variables in the implementation of online learning with reference to the complexity of existing limitations.

In the midst of various limitations, character education during the Covid-19 pandemic must also continue to be carried out. Therefore, the significance of this research also lies in an in-depth study of how character education is implemented in rural areas with various limitations. Previous studies only examined character education in the family environment during the pandemic (Prabowo et al., 2020; Yoga Purandina \& Astra Winaya, 2020). The studies on the integration of character education in the curriculum that looked at how principals and teachers integrated it in the syllabus and lesson plans (Mustikaningrum et al., 2020). This study will provide an overview of the various obstacles, challenges, and learning strategies used by 
teachers in implementing distance learning and character education in rural areas. Constraints experienced by students with various supporting and inhibiting factors will also be illustrated from the case studies conducted. So, this study aims to find teacher strategies in distance learning and character education in rural areas.

\section{METHOD}

This research was a qualitative research that examined the teacher's strategy in implementing distance learning and character education in rural areas. The subjects of this study were 13 teachers from SDN 2 Perancak and SDN 1 Yehkuning located in the coastal area of Jembrana District, Jembrana Regency, Bali. There are six elementary schools in the rural area of Jembrana sub-district, two schools were selected as samples. The data in the study were collected through interview and observation for teacher strategy data in distance learning, while interview methods and questionnaire were used for teacher strategy data in carrying out character education. The grid of interview instruments and questionnaires used is as follows.

Tabel 1. The Grid of Interview Instruments and Questionnaires

\begin{tabular}{cccc}
\hline No & Aspect & Indicator & Question \\
\hline \multirow{2}{*}{1} & Distance Learning & Strategy Type & What strategies do you use during distance \\
& Strategies & Obstacle & learning? \\
& & What are the obstacles that you get? \\
2 & Character Building & Strategy & How is character education implemented in \\
& & Obstacle & distance learning? \\
& & & What are the obstacles that you get?
\end{tabular}

Data analysis went through three stage, namely data reduction, data presentation, and data verification. The technique used to check the validity of the data and the saturation of the data in this study was observation and data triangulation. The observation was meant to determine the characteristics and elements in a situation that were very relevant to the problem or issue being discussed and then focus on these things in depth. With this technique, a more detailed and in-depth picture of distance learning and character education strategies was obtained during the Covid-19 pandemic in rural areas. Meanwhile, the data triangulation technique used to check the validity of the data was by utilizing sources, methods, and theories.

\section{RESULT AND DISCUSSION}

\section{Result}

Data related to teacher strategies in distance learning were collected using unstructured interviews and observations of teachers at SDN 2 Perancak and SDN 1 Yeh Kuning. The results of interviews and observations show a number of obstacles faced by teachers in implementing distance learning. The obstacles faced by teachers were (1) feeling that they did not have sufficient ability in implementing distance learning; (2) limited time made teachers worried about achieving curriculum goals; (3) The limitations of learning facilities and infrastructure, such as cellphones owned by parents of students. Children in these rural areas live in areas with a supporting internet signal, and there were even cell towers for certain providers. However, the problem was that elementary students did not have cellphones to use for themselves. In-depth interviews showed that this situation was mostly not because they were considered unfit to have a cellphone, but rather because of the economic inability of parents. Especially during the pandemic, there were priority needs that must be considered by students' parents. The majority of the parents' occupations were fishermen and daily labourers. Other occupations were farmers, employees, and others. Another obstacle arose for students who had cellphones (owned by their parents) was the limited internet quota; (4) learning assistance for children; (5) Students found it difficult to learn from home, difficult to understand the material and concentrate; and (6) students' learning motivation was low.

Seeing these various obstacles, teachers took various steps so that distance learning during the Covid-19 pandemic could take place. Several steps or methods taken by the teacher were (1) Mapping the learning supporting factors; (2) self-reflection; (3) Establishing communication with parents of students (3) Discussing with fellow teachers regarding learning achievement targets during the Covid-19 pandemic; (4) Preparing materials, media, and assignments; (5) Preparing alternative strategies.During the pandemic, teachers remained in schools for the duration of time and arrangements that had been determined and by 
following strict health protocols. To be able to provide services to students' learning difficulties, teachers provided opportunities for students to ask questions to school while still paying attention to health protocols. Another alternative strategy was to make home visits. This strategy was often done by teachers at the beginning of the Covid-19 pandemic. However, when Covid-19 cases showed an increase, this strategy was discontinued.

The results on character education in rural areas showed that $29.4 \%$ of teachers carried out character education in a very limited way, namely only using Whatsapp Group to remind students about character values. This result was reinforced by the results of interviews which showed that the character values that were usually emphasized were faith, discipline, responsibility, and independence. The value of faith was emphasized through the activity of praying every day. Discipline values that were often emphasized were related to discipline in following government recommendations and parental messages. Meanwhile, the value of responsibility were related to the responsibility to complete the tasks given, while the value of independence that was emphasized was being independent in doing daily tasks such as making the bed, cleaning the room, and being independent in doing tasks. There were $23.5 \%$ of teachers who carried out character education in a limited manner in the form of inserting in reading texts and examples of behavior in the form of pictures. The teacher admited that this method was carried out because it was the most effective way because it could be applied to offline distance learning which was certainly not considered burdensome in terms of the economic burden during the pandemic and overcame the difficulties of students who did not have supporting facilities. Most often, teachers instilled character education through pictures because they felt it was the easiest to implement.

Another $23.5 \%$ of teachers carried out character education through joint activity monitoring. This monitoring involved parents of students. The teacher invited parents to discuss issues to provide an understanding of the importance of parental assistance in instilling character during the Covid-19 pandemic. This monitoring was carried out through a check list that had been prepared by the teacher in the form of a print out. This method was chosen so that parents did not feel burdened with the costs that must be incurred for this activity. The teacher also gave an explanation regarding how to work or the steps to carry out activities. The following was an example of character education through a check list filled out by students and monitored by parents.

Table 2. Student's Daily Activity Checklist

\begin{tabular}{|c|c|c|}
\hline No & Pertanyaan (Question) & Tanggal (Date) \\
\hline 1 & Bangun pagi (Up early) & \\
\hline 2 & $\begin{array}{l}\text { Mandi sesuai jam mandi (Take a shower according } \\
\text { to bath time) }\end{array}$ & \\
\hline 3 & $\begin{array}{l}\text { Makan dan membersihkan tempat makananmu } \\
\text { sendiri (Eat and clean your own food place) }\end{array}$ & \\
\hline 3 & Berdoa/sembahyang (pray) & \\
\hline 4 & $\begin{array}{l}\text { Membantu orang tua membersihkan rumah (Helping } \\
\text { parents clean the house) }\end{array}$ & \\
\hline 5 & Mengerjakan tugas sekolah (Doing homework) & \\
\hline 6 & Bermain tidak lupa waktu (Play doesn't forget time) & \\
\hline 7 & Tidur tidak larut malam (Sleep not late at night) & \\
\hline
\end{tabular}

Table 3. Student Weekly Activity Checklist

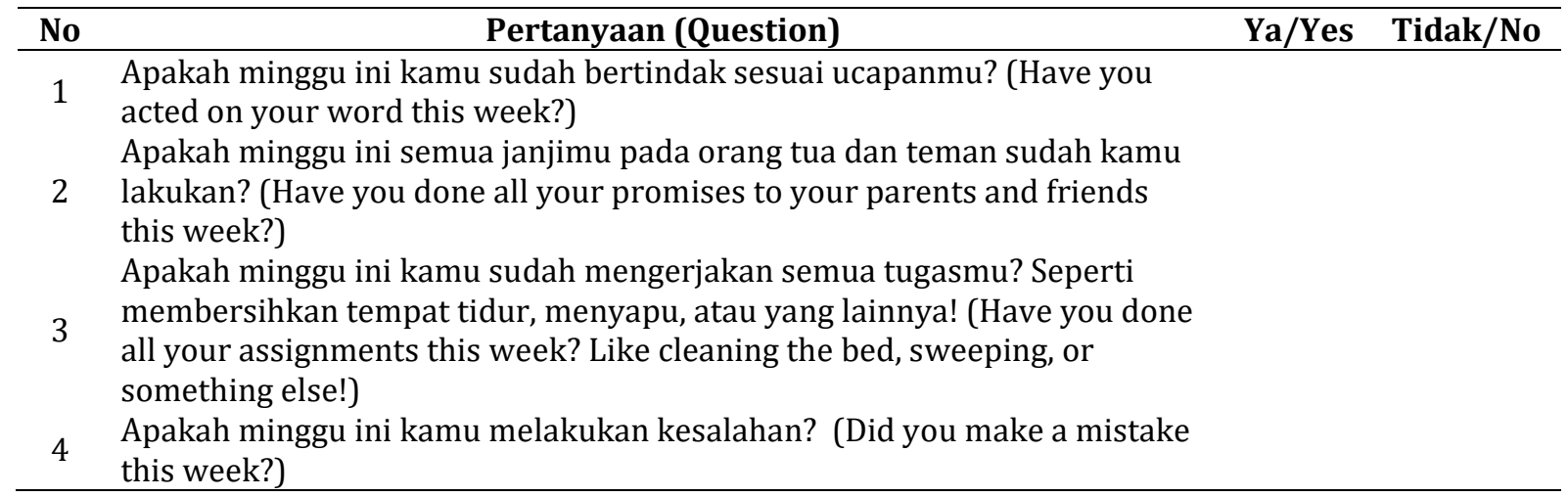




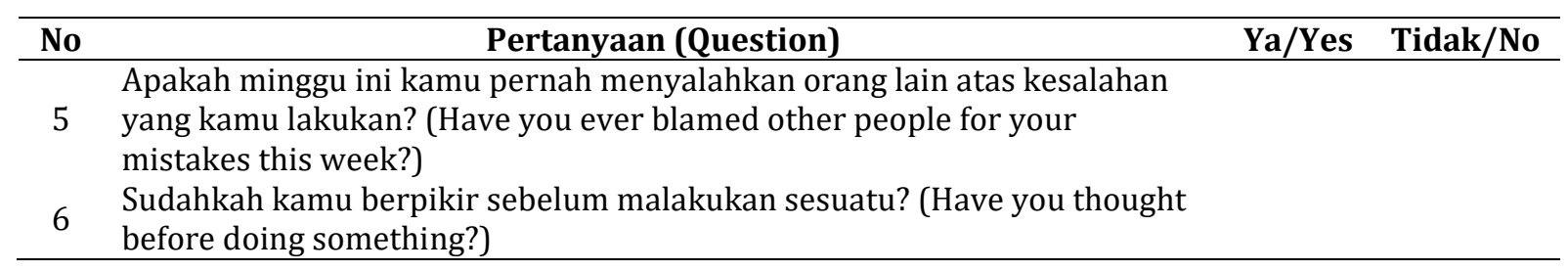

The research data shows that teachers made efforts to ensure that learning could still be carried out during the Covid-19 pandemic even though it was felt that it would not take place optimally. The feeling of unpreparedness in implementing distance learning was felt by teachers at the beginning of the pandemic. This situation was similar to the research findings which showed elementary school teachers at SDN Bluto 1 Sumenep were not ready to carry out distance learning, which in the end the learning was not optimal (Mamluah \& Maulidi, 2021). The results of this study were also similar to the results of research at SDN 16 Pagi Cengkareng Barat which showed teachers were less prepared and learning was less effective (Fitriya et al., 2021). However, this was not the case with the results of research on the readiness of 35 elementary school teachers in the Main Jakarta area which states that teachers in the North Jakarta area were ready to carry out online learning and learning took place effectively (Simatupang et al., 2020). Looking at these two situations, it appears that the teacher readiness factor will determine the effectiveness of distance learning. This is in line with the opinion that the readiness factor of teachers and the parties involved would determine the smoothness of distance learning (Azhari \& Fajri, 2021; Novianto et al., 2021). The results of the study also showed that teachers in rural areas were more likely to face technical and preparedness problems during the Covid-19 pandemic.

Various steps had been taken by the teacher to prepare learning in accordance with the goals and obstacles that have been mapped. The learning objectives to be achieved will determine what strategy will be used (Barnard et al., 2021; Rasmitadila et al., 2020; Wesolowski, 2015). A teacher must really understand the learning objectives before choosing a learning strategy. This step had been taken by the teachers of SDN 1 Yehkuning and SDN 2 Perancak by previously discussing with colleagues regarding the objectives or targets of learning outcomes. Teachers realized that choosing an appropriate learning strategy would enable the achievement of predetermined learning objectives. The selection of strategies carried out by teachers had taken into account various factors such as learning factors and the learning environment (learning environment). The results showed that the distance learning strategies implemented during the pandemic were divided into 2 main stages and 3 forms of distance learning strategies. Two distance learning strategies seen from the learning flow are distance learning strategies in the preparation stage of learning and distance learning strategies in the implementation stage of learning. The distance learning strategy in the learning preparation phase is carried out by analyzing the strengths and weaknesses of the supporting and inhibiting factors of learning, while the distance learning strategy in the implementation phase involves preparing alternative distance learning strategies according to the situation at hand. These alternative strategies are then called 3 forms of distance learning strategies in rural areas, namely online distance learning strategies, offline distance learning, and mixed distance learning. The following describes the distance learning strategies for the teachers of SDN 1 Yehkuning and SDN 2 Perancak.

The online distance learning strategy in rural areas was carried out using only Whatshap Groups (WAG). WAG was used to greet students and send assignments. If it was observed that WAG was the channel that was mostly chosen by teachers in distance learning, as seen in the results of other studies (Jalal, 2020; Septina et al., 2020; Setyaningsih, 2020). Apart from being considered the most popular and well-known, WhatsApp was also seen by teachers as an online channel that could be used to overcome the problem of teacher unpreparedness in implementing distance learning. Although there were teachers who understand the use of other apps such as google meet, schoology, or zoom, these apps were also not possible to be implemented due to existing limitations (Mpungose, 2021; Putra, 2021; Zhang et al., 2020) . It can be said that the distance learning strategy applied in rural areas was an online distance learning strategy based on whatsapp. Online distance learning could only take place in a very minimal amount of learning and could only be followed by a very limited number of students in one study group. Seeing the various obstacles faced, both from the teacher's side and from the student's side as well as the availability of facilities, offline distance learning strategies were considered the most appropriate. Offline distance learning was an alternative learning strategy in rural areas given the digital divide. The digital divide is the inability of individuals to feel the benefits of information technology due to lack of access and ability to use it (Churiyah et al., 2020). This digital gap in rural areas occurs because of the high operational costs felt by parents due to differences in socioeconomic levels in accessing opportunities to access information and communication technology and internet use (Goudeau et al., 2021; Indrawati et al., 2020). The digital divide is also felt by 
many teachers in rural areas. This digital gap is in the form of a gap in the ability to use information and communication technology.

The offline distance learning strategy occurs by means of the teacher preparing teaching materials/media and assignments for students/parents to take at school and bringing them home to study and do the assigned tasks. The weakness of this strategy is that there is no verbal explanation from the teacher at the beginning of the division of tasks. Students who do not understand can ask the school in turns so as not to cause a crowd. The tasks are then reassembled within the specified time duration. This offline distance learning strategy is a strategy that is also used in other rural areas, such as in several areas in West Sumatra (Abuhassna et al., 2020; Kurnia \& Lena, 2021). The results of the research provide an explanation that offline distance learning was chosen because of limited internet access and reasons for the economic level of students' parents (Kalyuga, 2012; Kurnia \& Lena, 2021). These findings have similarities and differences with the findings in this study. The similarity lies in the reasons for the economic conditions of the students' parents, while the difference lies in the reasons for the availability of internet access. Rural areas in this study have been reached by the internet, only because they did not have the gadgets used for learning.

The offline distance learning strategy demands more parental activity in the learning process. This is because it is in the hands of parents that mentoring and supervision occurs (Sonnenschein et al., 2021; Tamboto et al., 2021). Offline distance learning does not allow teachers to provide explanations or facilitation when students experience problems. This transfer of facilitation roles from teachers to parents is what happens in offline distance learning. The results of the research also emphasized the importance of parental activity in providing learning assistance for elementary students (Kurnia \& Lena, 2021; Slovaček \& Čosić, 2020). The activeness of parents in providing assistance is needed for low grade students. The results showed that there were many obstacles faced by offline distance learning in lower grade students. The lack of time for parental assistance and the inability of parents to provide assistance were the two main factors that hindered the occurrence. The same thing happened in Croatia in distance learning during the Covid-19 pandemic (Slovaček \& Čosić, 2020). Independent learning cannot be demanded for low-grade students who cannot read and write well. Therefore, the offline distance learning media that plays a very important role in rural areas is the parents of students. Many parents in rural areas feel they are under a greater burden during the COVID-19 pandemic. In fact, they often feel stressed (Sonnenschein et al., 2021; Susilowati \& Azzasyofia, 2020). Due to various obstacles, distance learning is also considered ineffective by parents and wants more interactive learning (Lau \& Lee, 2021).

The mixed distance learning strategy that occurs in rural areas is a combination of WAG-based online distance learning and offline distance learning by taking materials or assignments to school. This is done by the teacher seeing the various limitations that exist. Teachers use WAG to provide motivation and brief directions in providing direction related to learning activities. Some supporting materials and assignments are also distributed through WAG. Students who at that time could not access the group came to the school to pick up materials and assignments. the lesson. This mixed strategy was also implemented in an alternating pattern between online distance learning and offline distance learning with the reason that it did not burden parents with internet quota fees (Vernadakis et al., 2012; Yusoff et al., 2017; Yustina et al., 2020). The gap between individuals in terms of access to information and communication technology opportunities due to socio-economic differences really must be considered. The implementation of distance learning in rural areas is faced with various problems. However, the teachers tried to keep the learning going. The principles in designing distance learning could be fully implemented, several principles that could be implemented such as setting clear objectives. During the pandemic, teachers always discussed with other teachers in setting learning goals. Teachers prioritized essential goals according to the direction of the Ministry of Education and Culture; Material in small units; Giving stimulation by giving examples with pictures; and Providing feedback (Dietrich et al., 2020; Gul \& Khilji, 2021). The teacher trid to provide feedback even though not all assignments got them.

The results of the study on character education in rural areas indicated that teachers in rural areas strived for character education to continue to be implemented. There were 3 strategies to carry out character education during the Covid-19 pandemic, namely (1) through direct feedback (via whatsapp groups or directly when students took materials/tasks to school; (2) through examples or narratives in the text. The examples given were also in the form of pictures; and (3) through a check list of daily and weekly activities. Character values that were emphasized during the pandemic are faith, independence, discipline, and responsibility. Character values were instilled through giving examples in the form of narration and drawings in the material/tasks and habituation of students' daily activities. These two steps were in line with the the way of character education in the national character education strategy. The results of this study were also in line with the results of research conducted on one way of planting character through habituation activities (Asih \& Sunarso, 2020; Permatasari et al., 2021; Puspitasari et al., 2021; Wiyani, 
2020). While there were two other ways, namely exemplary and punishment were not found in a study in a rural area as was the case in other studies (Astuti et al., 2020; Permatasari et al., 2021). The feedback given by the teacher was not punishing, but rather to raise awareness of good behavior and emphasize honesty. From this, it can be seen that in addition to the values of faith, independence, discipline, and responsibility, the value of honesty in character learning in rural areas was also emphasized.

The teacher in the rural area invited students who have not been able to carry out the activities in the check list that was distributed. The teacher also gave appreciation so that the good habits that were strengthened and could be carried out continuously. This step was in line with three important domains/components in character education, namely moral knowing, moral feeling and moral action (Pike et al., 2021). Giving examples or models of character education through narration and pictures is a form of stages of civilizing the minds of students on character values. This step is a step in the cognitive domain (moral knowing) in character education carried out in rural areas. Meanwhile, giving advice or discussion between teachers and students and giving appreciation is a form of step in the affective domain (moral feeling), while habituation through a check list of activities that is monitored with cooperation from students' parents is a form of psychomotor activity (moral action). An overview of character education strategies in rural areas can be seen in Figure 1 below.

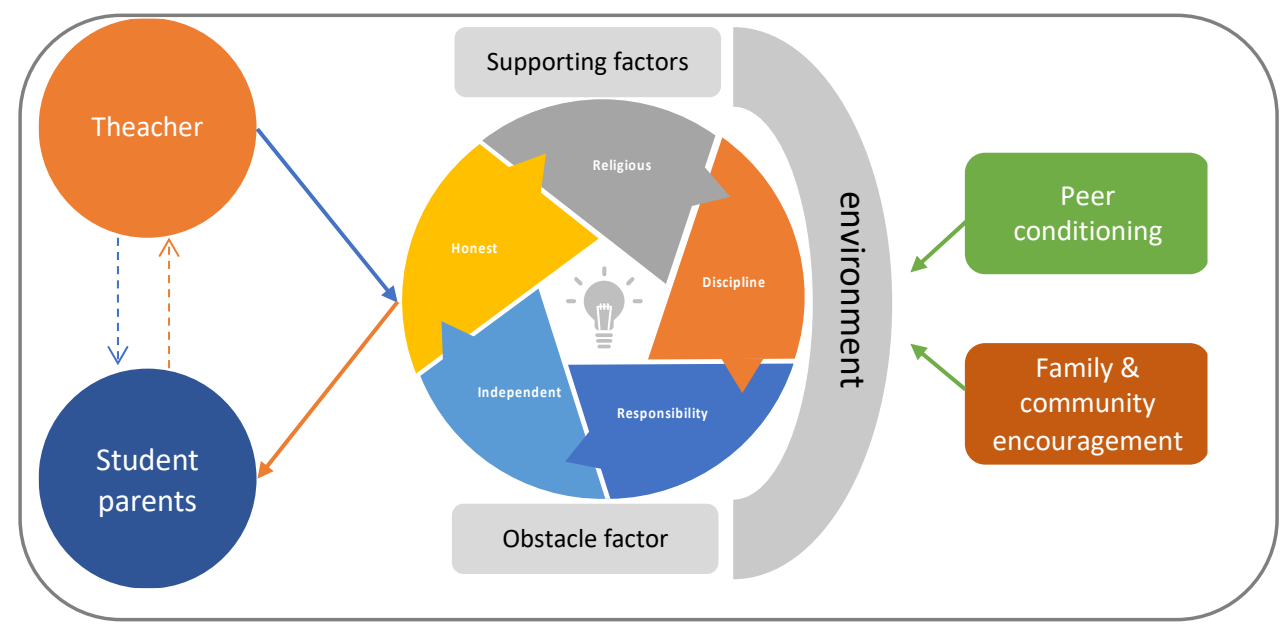

Figure 1. Character Education Strategy in Rural Area

Figure 1. shows the focus of character education values that can be pursued during the Covid-19 pandemic and the strategies carried out by teachers. Teachers instill character education with a focus on the values of faith, discipline, responsibility, independence, and honesty through various support channels, such as whatsapp groups, giving examples in the form of narratives and pictures in the material/tasks, discussions, advice, and appreciation of behavior. The teachers also provided a check list of daily activities to students. The teachers coordinated with parents regarding monitoring strategies through a check list of students' daily and or weekly activities (Saha et al., 2021; Slovaček \& Čosić, 2020). Parents then provided support in the form of sending the results of the monitoring check list that had been filled in by the parents to the teacher. From the check list from parents, the teachers compared it with the check list made by the students themselves. The teacher then invited students to discuss the discrepancy of the check list and on the other hand gave appreciation for students who carried out activities according to the existing list of activities. The process of character education was influenced by the environment, in the form of supporting and inhibiting factors in the form of facilities and economic constraints of parents of students. To create a supportive environment, teachers conditioned peers with similar check lists and provide understanding to parents regarding the importance of the role of family and community in children's character education (Mali \& Lim, 2021; Muradi et al., 2021; Yigzaw et al., 2019). This was done considering the knowledge and awareness of parents regarding the role of parents in character education was still low. This was similar to the research findings that parents' understanding was still low regarding character education (Sabrina et al., 2021; Setiawan et al., 2020). In addition, parents were busy at work every day (Fortuna et al., 2020; Lase et al., 2021; Wang, 2020). The success of character education really requires the synergy and collaboration of various parties to realize effective learning and character education. 


\section{CONCLUSION}

The limitations that exist in rural areas in implementing distance learning and character education during the COVID-19 pandemic have made teachers seek various strategies. In rural areas with the support of facilities that are not the same among students, online learning is not fully implemented. Character education also runs in the offline proportion which is mostly done. Despite its limitations, cooperation between teachers and parents plays an important role in the implementation of character education.

\section{REFERENCES}

Abuhassna, H., Al-Rahmi, W. M., Yahya, N., Zakaria, M. A. Z. M., Kosnin, A. B. M., \& Darwish, M. (2020). Development of a new model on utilizing online learning platforms to improve students' academic achievements and satisfaction. International Journal of Educational Technology in Higher Education 2020 17:1, 17(1), 1-23. https://doi.org/10.1186/S41239-020-00216-Z.

Aditya, D. S. (2015). Embarking digital learning due to COVID-19: Are teachers ready? Journal of Technology and Science Education, 11(1), 104-116. https://doi.org/https://doi.org/10.3926/jotse.1109.

Aji, R. H. S. (2020). Dampak Covid-19 pada Pendidikan di Indonesia: Sekolah, Keterampilan, dan Proses Pembelajaran. Jurnal Sosial Dan Budaya Syar-I, 7(5). https://doi.org/10.15408/sjsbs.v7i5.15314.

Akhwani, \& Romdloni, M. A. (2021). Indonesian Journal of Primary Education. Indonesian Journal of Primary Education, 5(1), 1-12. https://doi.org/https://doi.org/10.17509/ijpe.v5i1.31381.

Andarwulan, T., Al Fajri, T. A., \& Damayanti, G. (2021). Elementary teachers' readiness toward the online learning policy in the new normal era during Covid-19. International Journal of Instruction, 14(3), 771-786. https://doi.org/10.29333/iji.2021.14345.

Arkiang, F. (2021). Analisis Pembelajaran Daring Selama Pandemi Covid-19 Di Daerah 3T (Nusa Tenggara Timur). Jurnal Pendidikan, 12(Vol 12, No 1 (2021)), 57-64. https://doi.org/https://dx.doi.org/10.31258/jp.12.1.57-64.

Asih, P., \& Sunarso, A. (2020). Implementation of Character Education to Improve the Students Discipline Through Habituation of Nadzam Asmaul Husna Recitation at Grade IV. Elementary School Teacher, 3(1). https://doi.org/10.15294/est.v3i1.28035.

Astuti, A. D., Suyatno, S., \& Yoyo, Y. (2020). The Strategy of Principal In Instilling Religious Character In Muhammadiyah Elementary School. The European Educational Researcher, 3(2), 67-85. https://doi.org/10.31757/euer.323.

Atsani, K. L. (2020). Transformasi Media Pembelajaran Pada Masa Pandemi Covid-19. Jurnal Teknologi Pendidikan, $22(1)$

65-70. https://doi.org/https://doi.org/10.47730/jurnallampuhyang.v11i2.194.

Ayuni, D., Marini, T., Fauziddin, M., \& Pahrul, Y. (2021). Kesiapan Guru TK Menghadapi Pembelajaran Daring Masa Pandemi Covid-19. Jurnal Obsesi: Jurnal Pendidikan Anak Usia Dini, 5(1). https://doi.org/10.31004/obsesi.v5i1.579.

Azhari, B., \& Fajri, I. (2021). Distance learning during the COVID-19 pandemic: School closure in Indonesia. International Journal of Mathematical Education in Science and Technology. https://doi.org/10.1080/0020739X.2021.1875072.

Barnard, M., Whitt, E., \& McDonald, S. (2021). Learning objectives and their effects on learning and assessment preparation: insights from an undergraduate psychology course. Assessment and Evaluation in Higher Education, 46(5), 673-684. https://doi.org/10.1080/02602938.2020.1822281.

Bokayev, B., Torebekova, Z., Abdykalikova, M., \& Davletbayeva, Z. (2020). Exposing policy gaps: the experience of Kazakhstan in implementing distance learning during the COVID-19 pandemic. Transforming Government: People, Process and Policy, 15(2), 275-290. https://doi.org/10.1108/TG-07-2020-0147.

Cha, H., \& So, H.-J. (2021). Online Learning in K-12 Schools Amid Covid-19 in South Korea: Challenges and Opportunities. In Radical Solutions for Education in a Crisis Context. Lecture Notes in Educational Technology. https://doi.org/10.1007/978-981-15-7869-4_20.

Churiyah, M., Sholikhan, S., Filianti, F., \& Sakdiyyah, D. A. (2020). Indonesia Education Readiness Conducting Distance Learning in Covid-19 Pandemic Situation. International Journal of Multicultural and Multireligious Understanding, 7(6), 491. https://doi.org/10.18415/ijmmu.v7i6.1833.

Dewi, W. A. F. (2020). Dampak COVID-19 terhadap Implementasi Pembelajaran Daring di Sekolah Dasar. Edukatif: Jurnal Ilmu Pendidikan, 2(1), 55-61. https://doi.org/10.31004/edukatif.v2i1.89.

Dietrich, N., Kentheswaran, K., Ahmadi, A., Teychene, J., Bessiere, Y., Alfenore, S., Laborie, S., Bastoul, D., Loubiere, K., Guigui, C., Sperandio, M., Barna, L., Paul, E., Cabassud, C., Line, A., \& Hebrard, G. (2020). Attempts, successes, and failures of distance learning in the time of covid-19. Journal of Chemical 
Education, 97(9), 2448-2457. https://doi.org/10.1021/acs.jchemed.0c00717.

Fitriya, D., Magdalena, I., \& Fauziah Fadhillahwati, N. (2021). Konsep Pembelajaran Daring di Era Pandemi Covid-19. Cerdika: Jurnal Ilmiah Indonesia, 182-188. https://doi.org/10.36418/cerdika.v1i3.30.

Fortuna, A. P., Rida, A. M., Maharani, L. S. P., Ardiansyah, R., \& Sari, A. A. (2020). A needs analysis of digital connecting book in education in the pandemic era. ACM International Conference Proceeding Series. https: //doi.org/10.1145/3452144.3452154.

Goudeau, S., Sanrey, C., Stanczak, A., Manstead, A., \& Darnon, C. (2021). Why lockdown and distance learning during the COVID-19 pandemic are likely to increase the social class achievement gap. Nature Human Behaviour. https://doi.org/10.1038/s41562-021-01212-7.

Gul, R., \& Khilji, G. (2021). Exploring the need for a responsive school curriculum to cope with the Covid-19 pandemic in Pakistan. Prospects. https://doi.org/10.1007/s11125-020-09540-8.

Hanesty, E., Neviyarni, N., \& Karneli, Y. (2020). Factors affecting student learning motivation during the Covid-19 pandemic. International Journal of Applied Counseling and Social Sciences, 02(1), 100-107. https: //doi.org/10.24036/005404ijaccs.

Indrawati, M., Prihadi, C., \& Siantoro, A. (2020). The Covid-19 Pandemic Impact on Children's Education in Disadvantaged and Rural Area Across Indonesia. International Journal of Education (IJE), 8(4), 1933. https://doi.org/10.5121/ije.2020.8403.

Jalal, M. (2020). Kesiapan Guru Menghadapi Pembelajaran Jarak Jauh Di Masa Covid-19. SMART KIDS: Jurnal Pendidikan Islam Anak Usia Dini, 2(1), 35. https://doi.org/10.30631/smartkids.v2i1.61.

Joaquin, J. J. B., Biana, H. T., \& Dacela, M. A. (2020). The Philippine Higher Education Sector in the Time of COVID-19. Frontiers in Education, 5(October), 1-6. https://doi.org/10.3389/feduc.2020.576371.

Kalyuga, S. (2012). Interactive distance education: A cognitive load perspective. Journal of Computing in Higher Education. https://doi.org/10.1007/s12528-012-9060-4.

Kurnia, W., \& Lena, M. S. (2021). Pengaruh Pembelajaran Jarak Jauh (PJJ)LuringTerhadap Hasil $\begin{array}{llll}\text { BelajarSiswaSD. Jurnal Pendidikan } & \text { Tambusai, }\end{array}$ https://doi.org/https://doi.org/10.31004/jptam.v5i1.1161.

Lase, D., Zega, T. G. C., \& Daeli, D. O. (2021). Parents' Perceptions of Distance Learning during COVID-19 Pandemic in Rural Indonesia. SSRN Electronic Journal, 13(2), 101-111. https://doi.org/10.2139/ssrn.3890610.

Lau, E. Y. H., \& Lee, K. (2021). Parents' Views on Young Children's Distance Learning and Screen Time During COVID-19 Class Suspension in Hong Kong. Early Education and Development, 32(6), 863-880. https: //doi.org/10.1080/10409289.2020.1843925.

Lemay, D. J., Bazelais, P., \& Doleck, T. (2021). Transition to online learning during the COVID-19 pandemic. Computers in Human Behavior Reports, 4, 100130. https: //doi.org/10.1016/j.chbr.2021.100130.

Mali, D., \& Lim, H. (2021). How do students perceive face-to-face/blended learning as a result of the Covid19 pandemic? International Journal of Management Education, 19(3), 100552. https://doi.org/10.1016/j.ijme.2021.100552.

Mamluah, S. K., \& Maulidi, A. (2021). Pembelajaran Jarak Jauh (PJJ) di Masa Pandemi COVID-19 di Sekolah Dasar. Jurnal Basicedu, 5(2). https: //doi.org/10.31004/basicedu.v5i2.800.

Mansur, H., Jumadi, Mastur, Utama, A. H., \& Prastitasari, H. (2021). The Problem of Distance Learning During the Covid-19 Pandemic. Ilkogretim Online - Elementary Education Online, 20(4), 168-175. https://doi.org/doi: 10.17051/ilkonline.2021.04.19.

Mpungose, C. B. (2021). Lecturers' reflections on use of Zoom video conferencing technology for e-learning at a South African university in the context of coronavirus. African Identities. https: //doi.org/10.1080/14725843.2021.1902268.

Muradi, A., Islam, U., Antasari, N., \& Kalimantan, S. (2021). Revitalization of Education for Children in Indonesian Families During the Covid-19 Pandemic. Ilköğretim Online, 20(3), 481-490. https: //doi.org/10.17051/ilkonline.2021.03.48.

Mustikaningrum, G., Pramusinta, L., Ayu, S., \& Umar, M. (2020). Kurikulum Dan Metode Pembelajaran Pada Masa Pandemi Covid-19 the Implementation of Character Education Integrated To Curriculum and Learning Methods During Covid-19 Pandemic. AULADUNA: Jurnal Pendidikan Dasar Islam, 7(2), 154-164. https://doi.org/https://doi.org/10.24252/10.24252/auladuna.v7i2a5.2020.

Novianto, G. D., Herman, D. A., \& Hadiapurwa, A. (2021). Jurnal Inovasi Pendidikan dan Pembelajaran Sekolah Dasar Pelaksanaan Pendidikan Jarak Jauh bagi Pendidik dan Peserta Didik di Masa Pandemi Covid19 di Sekolah Dasar. 4, 98-111. https://doi.org/https://doi.org/10.24036/jippsd.v4i2.112590.

Permatasari, N. A., Setiawan, D., \& Kironoratri, L. (2021). Model Penanaman Karakter Disiplin Siswa Sekolah

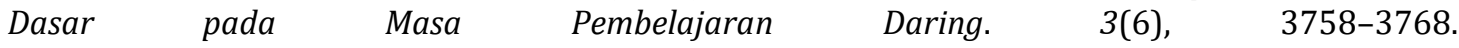
https: //doi.org/https://doi.org/10.31004/edukatif.v3i6.1303. 
Pike, M. A., Hart, P., Paul, S. A. S., Lickona, T., \& Clarke, P. (2021). Character development through the curriculum: teaching and assessing the understanding and practice of virtue. Journal of Curriculum Studies, 53(4), 449-466. https://doi.org/10.1080/00220272.2020.1755996.

Prabowo, S. H., Fakhruddin, A., \& Rohman, M. (2020). Peran Orang Tua Dalam Pembentukan Karakter Anak Di Masa Pandemi Covid-19 Perspektif Pendidikan Islam. Pendidikan Islam, 11(2), 191-207. https://doi.org/https: //doi.org/10.24042/atjpi.v11i2.7806.

Pradana, D. A., Mahfud, M., Hermawan, C., \& Susanti, H. D. (2021). Nasionalism: Character Education Orientation in Learning Development. Budapest International Research and Critics Institute (BIRCIJournal): Humanities and Social Sciences, 3(4), 4026-4034. https://doi.org/10.33258/birci.v3i4.1501.

Puspitasari, F. F., Mukti, T. S., Supriyanto, \& Munadi, M. (2021). Character Building Through the Synergy Between Parents and School in Indonesia. Proceedings of the International Conference on Engineering, Technology and Social Science (ICONETOS 2020), 529(Iconetos 2020), 16-21. https://doi.org/10.2991/assehr.k.210421.003.

Putra, R. W. P. (2021). Improving the Students' Motivation in Learning English through Google Meet during the Online Learning. English Learning Innovation, 2(1), 35-42. https://doi.org/10.22219/englie.v2i1.14605.

Rasmitadila, Aliyyah, R. R., Rachmadtullah, R., Samsudin, A., Syaodih, E., Nurtanto, M., \& Tambunan, A. R. S. (2020). The Perceptions of Primary School Teachers of Online Learning during the COVID-19 Pandemic Period : A Case Study in Indonesia. Journal of Ethnic and Cultural Studies, 7(2), 90-109. https://doi.org/http://dx.doi.org/10.29333/ejecs/388.

Sabrina, U., Ardianti, S. D., \& Ermawati, D. (2021). Kendala dalam Menumbuhkan Karakter Religius Anak Usia Sekolah Dasar selama Pandemi Covid 19. Edukatif : Jurnal Ilmu Pendidikan, 3(5), 3079-3089. https://doi.org/https://doi.org/10.31004/edukatif.v3i5.1233.

Saha, A., Dutta, A., \& Sifat, R. I. (2021). The mental impact of digital divide due to COVID-19 pandemic induced emergency online learning at undergraduate level: Evidence from undergraduate students from Dhaka City. Journal of Affective Disorders, 294(June), 170-179. https: //doi.org/10.1016/j.jad.2021.07.045.

Sari, Sinaga, Hernani, \& Solfarina. (2020). Chemistry Learning via Distance Learning during the Covid-19 Pandemic. TADRIS (Journal of Education and Teacher Training), 5(1). https: //doi.org/10.24042/tadris.v5i1.6346.

Septina, L. D., Nisa, K., \& Istiningsih, S. (2020). Analisis hambatan pembelajaran jarak jauh oleh guru pada masa pandemi covid-19 di SDN 41 Ampera. Jurnal Ilmiah Pendas: Primary Education Journal, 1(2), 85-89. https://doi.org/https://doi.org/10.29303/pendas.v1i2.63.

Setiawan, J. A., Suparno, Sahabuddin, C., Tasrif, \& Ramadhan, S. (2020). The role of parents on the character education of kindergarten children aged 5-6 years in bima. Universal Journal of Educational Research, 8(3), 779-784. https://doi.org/10.13189/ujer.2020.080307.

Setyaningsih, K. D. (2020). Analisis Pelaksanaan Pembelajaran Jarak Jauh Di Sd Negeri Karangrena 03. Jurnal Riset Pendidikan Dasar (JRPD), 1(2), 19-27. https://doi.org/10.30595/.v1i2.9012.

Simatupang, N. I., Sitohang, S. R. I., Situmorang, A. P., \& Simatupang, I. M. (2020). Efektivitas pelaksanaan pengajaran online pada masa pandemi covid-19 dengan metode survey sederhana. Jurnal Dinamika Pendidikan, 13(2), 197-203. https://doi.org/https://doi.org/10.51212/jdp.v13i2.1754.

Simbolon, M. E., Adi, Y. K., Angraeni, S., \& Pratiwi, D. P. (2021). Teacher Personality Competencies As Character. 2(1). https://doi.org/10.25134/ijete.v2i1.4140.

Sindiani, A. M., Obeidat, N., Alshdaifat, E., Elsalem, L., Alwani, M. M., Rawashdeh, H., Fares, A. S., Alalawne, T., \& Tawalbeh, L. I. (2020). Distance education during the COVID-19 outbreak: A cross-sectional study among medical students in North of Jordan. Annals of Medicine and Surgery, 59, 186-194. https: //doi.org/10.1016/J.AMSU.2020.09.036.

Slovaček, K. A., \& Čosić, G. (2020). The Role of Parents during the COVID19 Pandemic in Croatia. Studies in Educational Management, 8(8), 9-17. https://doi.org/10.32038/sem.2020.08.02.

Sonnenschein, S., Grossman, E. R., \& Grossman, J. A. (2021). U.S. parents' reports of assisting their children with distance learning during covid-19. Education Sciences, 11(9). https: //doi.org/10.3390/educsci11090501.

Stojanović, J., Petkovic, D., Alarifi, I. M., Cao, Y., Denic, N., \& Ilic, J. (2021). Application of distance learning in mathematics through adaptive neuro-fuzzy learning method. Computers \& Electrical Engineering, 93. https://doi.org/10.1016/j.compeleceng.2021.107270.

Susilowati, E., \& Azzasyofia, M. (2020). The parents stress level in facing children study from home in the early of covid-19 pandemic in Indonesia. International Journal of Science and Society, 2(3), 1-12. https://doi.org/https://doi.org/10.200609/ijsoc.v2i3.117. 
Tamboto, H., Tambingon, H. N., Lengkong, J. S. ., \& Rotty, V. N. J. (2021). The Involvement of Students' Parents in Organizing the Learning from Home at Elementary Schools in Tomohon City. Asia Pacific Journal of Management and Education, 4(1), 35-51. https://doi.org/10.32535/apjme.v4i1.1044.

Tiwery, W. Y., Patty, F. N., \& Nanlohy, D. F. (2021). Role Of Family For Children's Education During A Pandemic In Eastern Indonesia. Turkish Journal of Computer and Mathematics Education (TURCOMAT), 12(7), 1522-1527. https: //doi.org/https://doi.org/10.17762/turcomat.v12i7.2965.

Vernadakis, Giannous, Derri, Michalopoulos, \& Kioumourtzoglou. (2012). The impact of blended and traditional instruction in students performance. In Procedia Technology, 1(1), 439-443. https://doi.org/10.1016/j.protcy.2012.02.098

Wang, K. Y. C. (2020). Information Behavior of Parents during COVID-19 in Relation to Their Young Schoolage Children's Education. Serials Librarian, $79(1-2), \quad 62-77$. https://doi.org/10.1080/0361526X.2020.1806179

Wesolowski, B. C. (2015). Tracking Student Achievement in Music Performance. Music Educators Journal, 102(1), 39-47. https://doi.org/10.1177/0027432115589352

Wiyani, N. A. (2020). Implementation of a Character Education Strategy in the Perspective of Permendikbud Number 23 of 2015 at Raudhatul Athfal. Tarbawi: Jurnal Keilmuan Manajemen Pendidikan, 6(02), 141. https://doi.org/10.32678/tarbawi.v6i02.2934.

Yigzaw, M., Tebekaw, Y., Kim, Y.-M., Kols, A., \& Ayalew, F. (2019). Comparing the effectiveness of a blended learning approach with a conventional learning approach for basic emergency obstetric and newborn care training in Ethiopia. Midwifery, 78. https://doi.org/10.1016/j.midw.2019.07.014.

Yoga Purandina, I. P., \& Astra Winaya, I. M. (2020). Pendidikan Karakter di Lingkungan Keluarga Selama Pembelajaran Jarak Jauh pada Masa Pandemi COVID-19. Cetta: Jurnal Ilmu Pendidikan, 3(2), 270290. https://doi.org/10.37329/cetta.v3i2.454.

Yusoff, S., Yusoff, R., \& Noh, N. . (2017). Blended Learning Approach for Less Proficient Students. SAGE Open, 7(3), 1-8. https://doi.org/10.1177\%2F2158244017723051.

Yustina, Syafii, W., \& Vebrianto, R. (2020). The effects of blended learning and project-based learning on pre-service biology teachers' creative thinking skills through online learning in the COVID-19

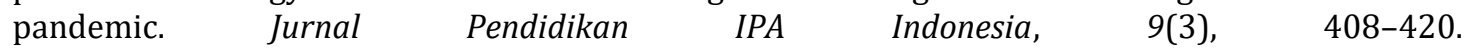
https://doi.org/10.15294/jpii.v9i3.24706.

Zhang, Y., Ghandour, A., \& Shestak, V. (2020). Using Learning Analytics to Predict Students Performance in Moodle LMS. International Journal of Emerging Technologies in Learning. https://doi.org/10.3991/ijet.v15i20.15915. 